Abstract THU0242 - Table 1. Maternal disease activity and pregnancy outcomes in axSpA patients

\begin{tabular}{|c|c|c|c|c|c|}
\hline \multirow{2}{*}{\multicolumn{6}{|c|}{ 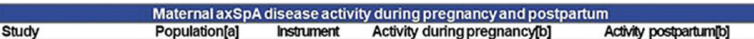 }} \\
\hline & & & & & \\
\hline Ursin 2017[c][d] & axSpA: $181 / 168$ & BASDAI & \multicolumn{2}{|c|}{$\begin{array}{l}\text { 'Stable, low disease activit' } \\
\left(2^{\infty} \text { timester. BASDAl=3.97) }\right.\end{array}$} & $\begin{array}{l}\text { 'Stable, low disease activity' } \\
\text { (6 weeks pp: BASDAl=3.46) }\end{array}$ \\
\hline Förger 2009[e] & ASt: 10 & BASDAI & \multicolumn{2}{|c|}{ 'Moderate disease activity' } & 'Stable' (2/10) \\
\hline Förger 2005[e] & AS $\{$ : 10 & BASDAI & \multicolumn{2}{|c|}{$\begin{array}{l}\text { 'Clinical improvement' (4/10) } \\
\text { 'Remained active' (6/10) }\end{array}$} & Notreported \\
\hline van den Brand & axSpAlg): 37 & ASDAS-CRP & \multicolumn{2}{|c|}{ 'Persistent high activity[h] } & 'Persistent high activity[h] \\
\hline Timur 2016[] & ASff: 20 & ASDAS-CRP & \multicolumn{2}{|c|}{$\begin{array}{l}\text { 'Decreased score' }(14 / 20) \\
\text { 'Unchanged score' }(620)\end{array}$} & $\begin{array}{l}\text { 'Decreased score' }(220) \\
\text { 'Unchenged score' }(3 / 20) \\
\text { 'Increased score'(15/20) }\end{array}$ \\
\hline \multirow{2}{*}{\multicolumn{6}{|c|}{$\begin{array}{l}\text { Pregnancy outcomes of axSpA patients and healthy controls } \\
\text { tions[a] } \\
\text { Incidenceper pregnandes vs controls }\end{array}$}} \\
\hline & & & & & \\
\hline Fang 2017|c|[d] & $\begin{array}{c}\text { AS: } 2492 \\
\text { Contols: } 2,347,847\end{array}$ & \multicolumn{4}{|c|}{ 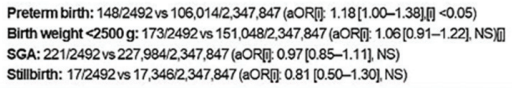 } \\
\hline $\begin{array}{l}\text { Förger } \\
\text { 2017(c)lle] }\end{array}$ & $\begin{array}{l}\text { axSpA: } 7870 \\
\text { Contols: } 70\end{array}$ & \multicolumn{4}{|c|}{$\begin{array}{l}\text { Preterm birth: higher risk } \\
\text { SGA: higher risk }\end{array}$} \\
\hline Park 2017[c][d] & $\begin{array}{l}\text { AS: } 27 / 20 \\
\text { Controls: } 108\end{array}$ & \multirow{2}{*}{\multicolumn{2}{|c|}{$\begin{array}{l}\text { Preterm birth: Data not reported (NS) } \\
\text { Lowbirth weight: } 22.2 \% \text { vs } 8.3 \%(0.024) \\
\text { Preterm birth: } 3220 \text { vs } 3 / 40(0.390) \\
\text { Birth welght } 2500 \text { g: } 5 / 20 \text { vs } 3 / 40(0.150)\end{array}$}} & \multicolumn{2}{|c|}{ Foetal loss: 0.27 vs 0/108(NS) } \\
\hline Timur 2016[d] & $\begin{array}{l}\text { ASff: } 20 \\
\text { Contols: } 40\end{array}$ & & & Abortic & n: $0.2+0.4$ vs $0.2+0.4(1.000)$ \\
\hline $\begin{array}{l}\text { Jakobsson } \\
\text { 2016[K }\end{array}$ & $\begin{array}{l}\text { ASI: } 199 \\
\text { Contols: } 477\end{array}$ & \multicolumn{2}{|c|}{ 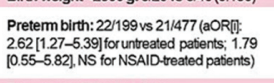 } & \multicolumn{2}{|c|}{$\begin{array}{l}\text { SGA: } 5 / 199 \text { vs } 6 / 477 \text { (aORT: } 1.34 \\
\text { [0.37-4.85], NS for untreated pabents; } \\
4.47[0.96-20.8] \text {, NS for NSAID-treated } \\
\text { pabents) }\end{array}$} \\
\hline $\begin{array}{l}\text { Ostensenand } \\
\text { Husby 1983:e] }\end{array}$ & $\begin{array}{l}\text { AS[f: } 13 \\
\text { Contols: } 31\end{array}$ & \multicolumn{2}{|c|}{$\begin{array}{l}\text { Preterm birth: } 1 / 13 \text { vs } 0 / 31 \\
\text { Miscarriage: } 0 / 13 \text { vs } 1 / 31\end{array}$} & \multicolumn{2}{|c|}{ Stillbirth: 0/13vs $1 / 31$} \\
\hline $\begin{array}{l}\text { aOR }[95 \% \text { co } \\
\text { aOR: adjustec } \\
\text { reactive prote } \\
\text { significant; NS }\end{array}$ & $\begin{array}{l}\text { axtal spon } \\
\text { steroidal a }\end{array}$ & $\begin{array}{l}\text { York cri } \\
\text { Ids ratio }\end{array}$ & $\begin{array}{l}\text { SAS classifica } \\
\text { at } 1.19 \text { (1.03- }\end{array}$ & & 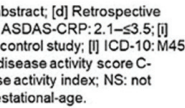 \\
\hline
\end{tabular}

REFERENCES:

[1] van den Brandt S. Arthritis Res Ther 2017;19(1):64.

[2] Jethwa H. Arthritis Rheumatol 2016;68(suppl 10).

[3] Jakobsson GL. Ann Rheum Dis 2016;75(10):1838-42.

Acknowledgements: This study was funded by UCB Pharma. Editorial services were provided by Costello Medical.

Disclosure of Interest: A. Moltó Grant/research support from: MSD, AbbVie, Pfizer, UCB Pharma, Consultant for: MSD, AbbVie, Pfizer, UCB Pharma, L. Gensler Grant/research support from: UCB Pharma, M. Clowse Grant/research support from: AbbVie, Bristol-Myers Squibb, Janssen, Pfizer, Consultant for: Pfizer, Janssen, UCB Pharma, H. Marzo-Ortega Grant/research support from: Janssen, Speakers bureau: Abbvie, Celgene, Janssen, MSD, Novartis, Pfizer, UCB Pharma, A. Artignan Employee of: Costello Medical, D. Goff-Leggett Employee of: Costello Medical, S. Leonard Employee of: Costello Medical, H. Resemann Employee of: Costello Medical, E. Thurtle Employee of: Costello Medical, N. de Peyrecave Employee of: UCB Pharma, C. Ecoffet Employee of: UCB Pharma, F. Förger Grant/research support from: UCB Pharma, Speakers bureau: Mepha, Roche, UCB Pharma

DOI: 10.1136/annrheumdis-2018-eular.3056

\section{THU0243 CASE FATALITY OVER 365 DAYS AFTER FIRST ACUTE CORONARY SYNDROME IN PATIENTS WITH ANKYLOSING SPONDYLITIS}

A. Södergren ${ }^{1}$, J. Askling ${ }^{2}$, K. Bengtsson ${ }^{3}$, H. Forsblad-D’Elia', T. Jernberg ${ }^{4}$, U. Lindström ${ }^{3}$, L. Ljung ${ }^{1,2}$, Ä. Mantel $\left.\right|^{2}$, L.T. Jacobsson ${ }^{3} .{ }^{1}$ Dept of public health and Clinical medicine/Rheumatology, Umeå University, Umeå; ${ }^{2}$ Clinical Epidemiology Section, Department of Medicine Solna, Karolinska Institutet, Stockholm; ${ }^{3}$ Department of Rheumatology and Inflammation Research, Sahlgrenska Academy at University of Gothenburg, Gothenburg; ${ }^{4}$ Dept of clinical sciences, Danderyd University Hospital, Karolinska Institutet, Stockholm, Sweden

Background: Ankylosing spondylitis (AS) is characterised by systemic and local inflammation of the axial skeleton, joints, and entheses. Studies have suggested a higher risk of acute coronary syndrome (ACS) among patients with AS compared with the general population, but whether patients with AS also have an increased fatality following ACS is not known.

Objectives: Is AS associated with an increased case fatality after a first-time ACS compared with the general population?
Methods: From the Swedish National Patient Register (NPR) we identified all patients registered with AS Jan 2001 through Dec 2014 and a later registration of a first time ACS between Jan 2006 and Dec 2014 ( $n=292)$. As a general population comparator, we identified up to 5 individuals per index-patient $(n=1276)$, matched on year of first ACS and birth, gender, and place of living. The follow-up period began at the date of admission for ACS and extended until death, emigration, 365 days of follow-up or 31 December 2014, whichever occurred first. Hazard ratios (HR) for death in the AS group vs. the general population comparator was assessed using Cox regression. We assessed HRs for death in two intervals: 30 day mortality (day 1 through 30), and mortality day 31 through 365 .

Results: During the 365 days following the ACS, $56(19 \%)$ of the 292 AS patients and $184(14 \%)$ of the 1276 population controls died (table 1). Whereas the 30 day mortality in the AS group was not elevated ( $\mathrm{HR}=0.9)$, the mortality day 31 through 365 was doubled compared with the general population ( $\mathrm{HR}=2.2$, table 1 and figure 1).

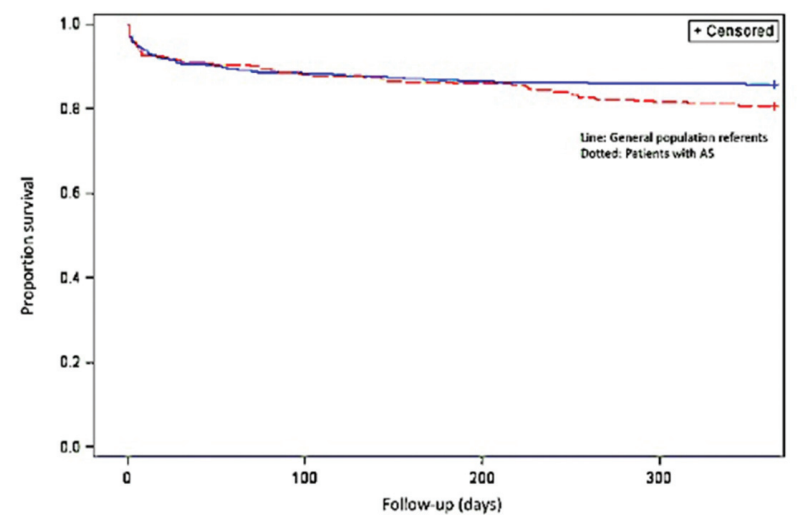

Abstract THU0243 - Figure 1. Kaplan-Meier curves showing survival after first ACS in patients with AS and general population referents during 365 days follow up.

Conclusions: Patients with AS were at increased risk of death during the firs year, though not during the first month, following ACS. It is yet not clear whether this could be due to factors associated with the AS disease per se, or differences in ACS characteristics or treatment.

Disclosure of Interest: A. Södergren: None declared, J. Askling Consultant for: $\mathrm{JA}$ and Karolinska Institutet had research agreements with Abbvie, BMS, MSD, Pfizer, Roche, Astra-Zeneca, Lilly, Samsung and UCB, mainly in the context of safety monitoring of biologics via ARTIS/The Swedish Biologics Register. For these, JA has been principal investigator. Karolinska Institutet has received remuneration for JA participating in ad boards arranged by Pfizer and Lilly, K. Bengtsson: None declared, H. Forsblad-D'Elia: None declared, T. Jernberg: None declared, U. Lindström: None declared, L. Ljung: None declared, Ä. Mantel: None declared, L. Jacobsson: None declared

DOI: 10.1136/annrheumdis-2018-eular.4074

\section{THU0244 HIGH PREVALENCE OF CLINICAL SPONDYLOARTHRITIS FEATURES IN PATIENTS WITH HIDRADENITIS SUPPURATIVA}

A. Rondags ${ }^{1}$, K.R. van Straalen ${ }^{2}$, S. Arends ${ }^{3}$, H.H. van der Zee ${ }^{2}$, E. Prens ${ }^{2}$, B. Horvath ${ }^{1}$, A. Spoorenberg ${ }^{3}{ }^{1}$ Dermatology, University of Groningen, University Medical Center Groningen, Groningen; ${ }^{2}$ Dermatology, Erasmus Medical Center, Rotterdam; ${ }^{3}$ Rheumatology and Clinical Immunology, University of Groningen, University Medical Center Groningen, Groningen, Netherlands

Background: Hidradenitis suppurativa (HS) is a chronic debilitating inflammatory skin disease and is associated with several comorbidities. HS and spondyloarthritis $(\mathrm{SpA})$ share several pathophysiological and clinical features, such as elevated cytokine levels of TNF- $\alpha$ and IL-17 and the association with inflammatory bowel

Abstract THU0243 - Table 1. Mortality and hazard ratios (HR) for patients with AS and general population referents during 365 days of follow up after a first ACS

\begin{tabular}{|c|c|c|c|c|c|c|c|}
\hline & \multirow{2}{*}{$\begin{array}{c}\text { Start } \\
\text { Individuals at risk }\end{array}$} & \multicolumn{3}{|c|}{ At 30 days follow up } & \multicolumn{3}{|c|}{ At 365 days follow up } \\
\hline & & Individuals at risk & $\mathrm{n}$ deaths & $\mathrm{HR}(95 \% \mathrm{Cl})$ day $0-30$ & Individuals at risk & $\mathrm{n}$ deaths & $\mathrm{HR}(95 \% \mathrm{Cl})$ day $31-365$ \\
\hline$\overline{\mathrm{AS}}$ & 292 & 273 & 26 & $0.9(0.6 ; 1.5)$ & 266 & 56 & $2.0(1.3 ; 3.1)$ \\
\hline General population comparator & 1276 & 1204 & 118 & ref & 1158 & 184 & ref \\
\hline
\end{tabular}

